\title{
The Roles of Community Engagement and Brand Community Types in Building Brand Trust on Social Media Based Brand Communities
}

\author{
Kurniadi Prastowo \\ STIE Manajemen Bisnis Indonesia, Depok 16951, Indonesia
}

\begin{abstract}
A B S T RA C T
This study aims to understand the influence of the four elements of the relationship or customer- centric model in the online brand community (relationship between customer-product, customer-brand, customer-company, and customer-other customers) on brand trust in the realm of social media, by measuring moderation effects of community engagement and brand community types. The respondents are 220 respondents, coming from two types of brand community: consumer-initiated and company-initiated brand community. In general, the measurement is done by using structural equation modeling method. The results of this study show that from the four elements of customer-centric in the online brand community (customer relationships with product, brand, company, and other customers), only customer-brand relationships that significantly affects brand trust. The results are different from previous studies, so it is interesting to investigate further. Furthermore, this research also found moderation effect of community engagement and community types in the relationship between online brand community and brand trust.
\end{abstract}

ARTICLE INFO

Article History:

Received : 14.11 .2019

Revised : :08.02.2020

Accepted : 08.02.2020

Published : 29.02.2020

Keywords:

Customer Centric Model

Online Brand Community

Brand Trust

Community Engagement

Brand Community Types

Social Media

*Corresponding Author E-mail:

kurniadiprastowo@stiembi.ac.id

Copyright $(2020$ Authors. This is an open access article distributed under the Creative Commons Attribution License, which permits unrestricted use, distribution, and reproduction in any medium, provided the original work is properly cited.

\section{INTRODUCTION}

The existence of internet greatly enhances a person's ability to interact and communicate with each other. Online brand communities become a place commonly used to share individual information and experiences about products and services, solve problems that consumers face, interact with other consumers and serve as company representatives (McWilliam, 2000). The development of social media is contributing in the emergence of various online brand community in social media, or so-called social media based brand community (SMBBC). Social media is also viewed as a highly efficient distribution and communication channel (Kaplan 
\& Heinlein, 2010), so that it provides benefits for the company, especially in terms of costs. With the existing benefits, company has seen the potential of marketing through social media, with intention to make company more optimal in marketing communication activities in offline and online, and can run these two things in an integrated manner.

Along with the popularity of the online brand community in social media, studies related to this topic also increased in number (Jung, Kim, \& Kim, 2014). Like it or not nowadays social media has been present in the midst of current marketing practices. Laroche, Habibi, dan Richard (2013) said that currently literatures that explore the effects of branding on marketing variables related to social media is needed. With the increasing number of SMBBC and the limited research on $\mathrm{SMBBC}$, research in this area is still interesting to do. In addition, previous research done is more focus on online brand community and brand community that are not based on social media, whereas SMBBC and brand community have different aspects such as community structure, social context in communicating, size, and way of giving information (Habibi, Laroche, \& Richard, 2014).

The phenomenon of online social networking, especially Facebook in Indonesia is growing rapidly. Based on the summary of world digital data from we are social internet users in Indonesia as of January 2016 reached 88.1 million users (data www.techinasia.com December 2016). While the number of Facebook users in Indonesia according to D'Silva (2016) as many as 82 million users in the fourth quarter of 2015. Kaplan and Haenlin (2010) classify social networking sites into one form of social media, they also claimed Facebook is one example of social networking sites. The large number of users and the ease of access into a big attraction for companies and customers in creating online brand community based social media using Facebook. With the ease of interaction and share various things between Facebook users, Facebook becomes a social media that has potential to be a means to promote various goods and services. Many small business owners see Facebook as an effective marketing tool and sales channel, enabling companies to gain new customers, improve communication effectiveness with customers, and finally better understand customers' needs (Chen Papazafeiropoulou, Chen, Duan, \& Liu, 2014).

In a brand community formed a relationship scheme, namely brand community triad, that is relationship between customer - brand, brand customer, and customer - other customers (Muniz and O'Guinn, 2001). Meanwhile, McAlexander, Schouten, and Koenig (2002) expanded the scheme into four customer-centric relationships model, which are: customer-product, customerbrand, customer-company, and customer-other customers. Brand trust is one of the main goals of marketing activities. This is because trust is important in consumer purchase process (Powers, Advincula, Austin, Graiko, \& Snyder, 2012). Brand trust is the willingness of customers to rely on the ability of a brand to perform in accordance with the promised function (Chaudhuri \& Holbrook, 2001). Some researchers have agreed that trusts are antecedents in create loyalty (Laroche et al., 2013). So this research focus on brand trust as outcomes from online brand community.

In addition to trust, interaction in the online brand community also allows the formation of engagement in a community. Algesheimer, Dholakia, \& Herrmann (2005) states that engagement is the wishes or attitudes of members of the community to increase the value of an online brand community. Community engagement is closely related to social media (Habibi et al. 2014), because the scope of behaviors included in community engagement are very extensive, such as: recommendations through WOM, helping other consumers, blogging, writing brand reviews, and involving in any legal actions relating to the brand (Van Doorn et al., 2010). However certainly not all customers or members of the community have the same level of engagement, for that Habibi et al. (2014) divide the level of engagement in the online brand community to low engagement and high engagement. 
The establishment or management of an online brand community not only can be done by the company, but customers can also do it. By using social media customers can easily form an online brand community, various features have been provided to form a brand community in social media. Therefore, there are two main types of online brand communities: First is consumerinitiated communities that are voluntarily built and managed by members, and the second are company-initiated communities that are built and managed by the company's brand owners (Kang, 2004; Jang, Olfman, Ko, Koh, \& Kim, 2008; Lee, Kim, \& Kim, 2011). Given the difference management in each type of online brand community, it allows different interaction between customer and product, brand, company and other customers in each type of online brand community.

Habibi et al. (2014) shows that customer-centric in an social media based brand community can influence brand trust and the level of engagement of members in it can also moderate this influence. But these results have not shown whether there is a difference in the influence of customer-centric on brand trust in the consumer-initiated and company-initiated communities. Thus, this research aim to measure and analyse the influence of customer-centric model (relationship between customer-product, customer-brand, customercompany, and customer-other customers) to brand trust, and will measure and analyze the effect moderation of community engagement and online brand community type in s ocial media based brand community.

\section{LITERATURE REVIEW}

\section{Brand Community}

In a community there are two main attributes: there is mutual influence between members and commitment to share shared values, meanings and historical identity (Etzioni and Etzioni, 1999). Each community also shows a specific organization, which collectively describes how to perform tasks on a specific domain (Wenger, McDermott, \& Snyder , 2002). It can be seen in a community in which it consists of a membership hierarchy and perform its tasks voluntarily. In short, the community is defined as an organization of individuals or small groups that have the intention to be together and have a sense of shared responsibility (Rheingold, 2002).

Consumption of branded goods communally is slowly shaping the brand community concept. The term brand community was first proposed by Muniz and O'Guinn (2001) in a study titled "Brand Community", in the study described the concept of brand community. Brand community is a specialized form of community, which has bonding and not based on geographical bonds, but rather based on a set of social relationships between specific brand enthusiasts (Muniz and O'Guinn, 2001). Meanwhile, according to Salomon (2015) brand community is a group of customers who share a set of social relationships based on the usage or interest of a product. Muniz and O'Guinn (2001) stated that the brand community is characterized as the follows:

1. Shared consciousness. Where members feel togetherness or know each other.

2. Rituals and traditions. Rituals and traditions serve as a preserving community culture. Examples of rituals and traditions carried out in brand communities are the celebration of brand history and the sharing of brand experiences.

3. Moral Responsibility. It is the overall sense of responsibility and obligation shared by all members of the community, and contributes to the collective and cohesive actions of the group.

In general there are several motivations for joining a brand community, among others: obtaining the utilitarian and hedonic values of a brand community (McAlexander et al. 2002; Schau, Muniz, \& Arnould, 2009), to meet the needs of identification with group symbols and build network with colleagues (Habibi et al., 2014),and to share the desire and excitement of the brand community also eek out important information about the brand (Zaglia, 2013). In addition, many people today follow a brand community driven by rewards offered by the company, especially 
discounts and other prizes for community members. McAlexander et al. (2002) describe four relationships in a brand community (customer-centric model), the relationship between customers with products, customers with brands, customers with companies, and customers with customers. These four relationships are an extension of the concept of relationship in the brand community of Muniz and O'Guinn (2001). In this research will use customer-centric model as the dimension of social media based brand community. McAlexander et al. (2002) in his research pronounces a brandfest operation in which there is a meaningful interaction of consumption experience, useful information, and other valuable things shared among customers and marketers in two ways, ultimately strengthening elements of the customercentric model.

\section{Brand Community Output for Company}

Nowadays companies are using internet as a means of establishing relationships with customers and developing brands, with the establishment of brand community they are able to interact and connect with each other. In the brand community, customers can play a role in helping companies to solve problems related to brands faced by other customers (Schau et al., 2009). Moreover, customers can also advocate for the brand (Habibi et al., 2014). Brand community is also a place to get productive feedback for the company (Jang, Olfman, Ko, Koh, \& Kim, 2008). It enables the company to evaluate and innovate its products in the future. The interactions within the brand community can also help companies identify the characteristics of their customers and needs more specifically, so companies can connect with customers efficiently (Hur, Ahn \& Kim, 2011).

Brand communities can also have a positive impact on adjustment stage of new products and prevent the adoption of new products derived from the brand's rivals (Thompson and Sinha, 2008). With the brand community the company can continuously share information in detail about new products offered to facilitate customer's adoption and minimize distraction from other products. In addition to the benefits, the company can also get negative things from the existence of brand community. Algesheimer et al. (2005) in his research indicates that brand community can bring normative pressure on its members resulting in resistance, decreased desire to recommend, decrease participation in the community, and lower loyalty. In addition, in social media is also very easy to spread electronic WOM (e-WOM), sharing on social media, on the other hand, is another form of eWOM (Jing, Sotheara, \& Virak, 2016). Therefore, the company must be prepared for all the effects of eWOM. The uniqueness of social media becomes an attraction for researchers, so in this research the online brand community will be examined in the context of social media and brand trust as outcomes from online brand community

\section{Social Media Based Brand Community}

Along with the emergence of social media and smartphones, consumers easily access the digital world or the internet. Today's consumers are very adept at using the internet, so that marketers are moving their marketing activities in the digital form, it has become one of the causes of transformation offline brand community becomes social media-based brand community (SMBBC). Social media is "an internet-based application group built on the foundation of Web 2.0 ideology and technology, and authorize the creation and exchange of user generated content" (Kaplan and Haenlein, 2010). User generated conten (UGC) is content created by users and can be disseminated, has a level of creativity and is not created by professionals, customers can access anytime to different media such as blogs, microblogs, video / photo spread sites, and social networks (Habibi etal., 2014).

The core essence of Web 2.0 is participation and interaction. This fit very well when it is linked with the concept of brand community which in its activities prioritize the participation and interaction between customers and sutomers as well as producers. Brogi (2014), revealsfour fundamental keys to the online brand community based on previous studies: 
1. The level of interaction and participation of members within the community and among themselves, the level of social involvement in the community (Casale, Flavianus \& Guinaliu 2010).

2. The level of relationship quality in the community and expressed in terms of satisfaction, which is the overall assessment by customers in the community about community sharing and benefits gained (Adjei, Noble, \& Noble, 2010; Casale et al., 2010).

3. The degree of identification, the extent to which customer feels themself as part of the community, recognizes equality with other members, and differs from non-members (Algesheimer et al., 2005; Casale et al., 2010).

4. The level of communication quality expressed in the four-dimensional period of information exchanged: timeliness, relevance, frequency, and duration (Adjei etal, 2010)

\section{Engagement Behavior in Facebook}

Someone who has joined the online brand community on Facebook, will generally interact with other members or at least receive notifications about the activities contained in it. When someone has started commenting, sharing experiences, interacting with the marketer about the brand, and answering questions in the comment field then the person is already involved in the brand community's online activity (Jing et al., 2016). Facebook provides several buttons to express the feelings of users and members of the community. The 'like' and 'share' buttons are often used as benchmarks of success of the online brand community. Aggregate the number of 'Likes' on the brand page is an indication of how popular the brand is in the eyes of customers (Jing et al., 2016).

Kabadayi and Price (2014) say that 'like' button helps companies promote and enhance brand awareness and engagement, which in turn contributes to ROI, while commenting on the brand page allows customers to share their opinions, wheteher they like or dislike the content on the brand page. In addition to 'like' button, the 'share' button also has a big contribution in the interaction in Facebook's as online brand community. Facebook users are quite easy to review about products and share their experiences online (Gvili \& Levy, 2016). Therefore, people who have been tied to a community and have a sense of ownership of the community will share information relating to the brand, and seek to benefit others (Bagozzi \& Dholakia, 2006). Currently the Facebook 'likes' button feature is developed into several types of emoticons (love, sad, laugh, shock, and angry), making the interaction option more representative of the user's expression or feelings for content.

\section{Social Media Based Brand Community and Brand Trust}

Brand trust is the willingness of consumers to rely on brand ability to perform the functions that have been declared by the brand (Chaudhuri \& Holbrook, 2001). Brand trust becomes very important factor for brand sustainability. In the concept of consumer loyalty trust is a strong mediator in the formation of brand loyalty (Laroche et al., 2013). When associated with an online brand community in social media, trust also has an important role. The nature of the digital world that is difficult to control makes the information received by customers can not be ascertained the truth. However, if the brand trust has been established then this can be anticipated, because customers feel comfortable with a brand that can be trusted (Chiu, Huang, \& Yen, 2010).

Habibi et al. (2014) say that there are two mechanisms that can increase trust in online brand communities: (1) Through information dissemination, social media provides a platform for customers to communicate about a brand they admire, customers easily connect with marketers and other customers, so that the relationship can positively affect brand trust. (2) The level of customer exposure to the brand and increase in customer interaction will develop relationships in the elements of the brand community. Therefore, the interaction of customers with marketers and with other consumers is very important in building trusts. The more interaction of the brand in the 
online brand community in social media the more exposure received by customers - from general things up to the details related to the brand.

The reality of customer relationships with products, brands, companies, and other customers in the online brand community, will cause a lot of information spread through status, photos, videos, and news shared by customers about a brand. The higher amount of interaction distributed of a brand in social media will leads customer to judge the brand more trustworthy (Habibi et al., 2014). Based on the above description the propose hypothesis is as follows :

$\mathbf{H}_{\mathbf{1}}$ : Customer relationship with (a) product, (b) brand, (c) company, (d) other-customers in online brand community, positively affects brand trust.

\section{Community Engagement}

Community engagement is defined as a deep consumer motivation to interact and cooperate with other members (Wirtz, Ambtman, Bloemer, Horvath, Ramaseshan, Klundert, Canli, \& Kandampully, 2013). From that sense thing that needs to be underlined is the interaction. As Brogi (2014) points out, the level of interaction and participation of members within community is one of the essential keys in the online brand community. Algesheimer et al. (2005) states that community engagement demonstrates the willingness of consumers to help other members, wishes to participate in community activities, the desire to support the community, in order to increase the brand's online value for themselves and others. In contrary, Wirtz et al. (2013) argues that community engagement not only shows attitudes (interest or desire), but also requires actual participatory behavior. So it can be said that community engagement is the identification of an online brand community that generates interactive participation in the online brand community (Brodie, Hollebeek, Juric, \& Ilic, 2011).

When a customer joins and has an attachment to an online brand community, the customer wants to get a value from both the brand and the organization (Wirtz et al., 2013). The positive experience gained from these interactions serves to strengthen customer relationships with brands (Algesheimer et al., 2010). Interaction in social media refers to activities such as sharing stories, photos, videos, liking and comments on community-related materials (Habibi et al., 2014).

Community engagement can be differentiated into low and high engagement. Higher engagement means higher co-operation and interaction, which through this interaction will produce a higher positive effect (Habibi et al., 2014). Habibi et al. (2014) also say consumers with higher levels of engagement will form stronger relationships with elements existing in the online brand community. Therefore community engagement is believed to moderate brand trust. Referring to Holmes's (1991) statement in Habibi et al. (2014), where theoretically, continuous interaction and longterm relationships will increase trust between parties, then the relationship between community engagement in the online brand community with brand trust will be stronger on customers with high engagement (Habibi et al., 2014). Therefore, community engagement will have a moderating effect on the influence of online brand communities on brand trust. Based on that, the proposed hypothesis are as follows:

$\mathbf{H}_{2}$ : Customer relationship with (a) product, (b) brand, (c) company, (d) other-customers in online brand community, stronger on high engagement customers, compared with low engagement customers.

$\mathbf{H}_{3}$ : Brand community engagement moderates the influence of customer-centric (customer relationships with (a) product, (b) brand, (c) company, (d) other-customers) on brand trust.

\section{Does Brand Community Type Affect?}

One of the key dimensions that significantly form an online brand community is funding and governance (Wirtz et al., 2013). Further Wirtz et al. (2013) said that online brand community can move with all funded and managed by the company (producer), or fully funded by community members who have enthusiasm for the brand. 
Even though more companies have formally established an online brand community, and have encouraged customers to build customer-created brand communities, the amount of researches on the online brand community domain that compares the effects of two types of online brand communities is still not many (Lee et al, 2011; Sung et al, 2010). In addition, no empirical studies related to the online brand community specifically address the moderating effects of the online type of brand community (Jung, Kim, \& Kim, 2014).

Jang, Olfman, Ko, Koh, and Kim (2008) revealed that in general online brand community can be classified into two types, namely: (1) consumerinitiated online brand community that was built voluntarily by customers and (2) the companyinitiated online brand community built by the company of a brand, aims to establish relationships with customers and get productive feedback for the company. Company-initiated communities have the advantage of detailed information and usability about the brand, in addition the company as a manager can also remove or block unfavorable comments from customers (Jang et al., 2008). Thus, what is displayed in the company-initiated community can be said to be not transparent, the lack or bad experience of the brand will most likely not reach all members. It is good for the company to keep its good name, but on the other hand consumers are not well informed about the shortcomings of the brand.

Given these differences then the different types of brand communities are also interesting to see any moderate effects on the online brand community's influence on brand trust. in this study, the online type of brand community will focus on classification based on the initiators of community-forming and managers who are divided into company-initiated and consumerinitiated online brand communities as research conducted by Jang et al. (2008).

In research conducted by Habibi et al. (2014), Study on the influence of customer-centric models on brand trusts is not tested whether there is a difference in the influence of brand trust on the online type of brand communities. Whereas in practice each community type has different interactions in it, while interaction is an important factor in the customer-centric model in the online brand community. Several previous studies have shown that there are differences from the online type of brand community towards commitment and participation (Jang et al., 2008; Sung, Kim, Kwon, \& Moon, 2010). However, some of these studies do not test the customer-centric model in the online brand community, but rather focus on the quality of information and systems, interaction, reward, and motivation. Some studies also show that brand trust is one of factor that shapes or influences commitment. Brand trusts affect consumer attitudes and brand-related issues, such as behavior including purchases, attitudes and loyalty, brand perception, commitment, and brand referrals (Chaudhuri \& Holbrook, 2001). From those description, the brand community types are perceived to have a moderating effect on the online brand community's influence on brand trust. based on the above, the proposed hypothesis is as follows:


Figure 1. Conceptual Model 
$\mathbf{H}_{4}$ : The types of online brand communities moderates the influence of customer-centric (customer relationships with (a) product, (b) brand, (c) company, (d) other-customers) on brand trust.

The model in Figure 1 is a conceptual model proposed in this study. The model illustrates the effects of customer-centric relationships on brand trusts, by measuring the moderating effects of community engagement. From this model can also be seen whether there are differences in the brand community's online relationship to brand trust when viewed from brand community types (consumer-initiated and company-initiated).

\section{RESEARCH METHOD}

\section{Subject and Procedure}

Number of respondents in this research is 220 respondents whom will be screened through the sreening questions in the questionnaire. The screening questions are: are you member of brand community in social media? This research will test moderation effect brand community types (consumer-initiated and company initiated online brand community), so the samples taken are from both types of communities. Sampling technique in this research using non-probability sampling technique. This is because the sample to be observed has certain criteria, or it can be said that the sample taken is based on subjective assessment from the researchers (Malhotra, 2010). The location of the study covers all areas of Indonesia, this is related to the nature of social media is not limited by geographical location. In addition, data retrieval done online also makes it easy to reach respondents unlimited by geographic location.

Questions on the second part of the questionnaire use a likert scale of 1 to 6 to measure indicators of each variables tested ( 1 is strongly disagree, 2 is disagree, 3 is somewhat disagree, 4 is somewhat agree, 5 is agree, and 6 is strongly disagree). From all the questionnaires distributed both online and offline, 226 questionnaires successfully collected, however only 220 able to meet the criteria set. Majority of respondents came from online brand community on Facebook, among others: Kawasaki Dtracker 150 (motorcycle), Polygon Collosus Riders (bike), Santa Cruz Indonesia (bicycle), Eiger Adventure (outdoor sport equipment), Consina The Outdoor (outdoor sport equipment), Honda Community (motorcycle) and 27 other communities. After being grouped by type of community, there were 117 data for consumerinitiated and 103 type for company-initiated type.

83.6\% of respondents use Facebook as their social media to interact in the online brand community. $36.8 \%$ of respondents held meetings with other members once a month, while $36.4 \%$ of the respondents never had a meeting. Gender is dominated by males by $90 \%$, for women as much as $10 \%$ of respondents. Most respondents were $26-30$ years age $(26.8 \%), 31-35$ years is $22.3 \%$, and $21-25$ years is $13.6 \%$

\section{Measures}

This study used some statistical analysis based on the nature and type of this study, which describes the variables measured descriptively and testing of the hypothesis proposed. Largely, the measurement is done using SEM method. Data processing using software SPSS 22 for Windows and LISREL 8.7. Customer-centric measurement model indicators are adopted from McAlexander, et al. (2002); Habibi et al. (2014), while community engagement was adopted from Algesheimer et al. (2005). The statement on the questionnaire uses a likert scale of 1 to 6 to measure indicators of each of the variables tested.

Pre-test evaluation is conducted amongst 50 respondents to check whether the measuring instruments used are appropriate and do not confuse respondents. All requirements of validity and reliability of pretest data can be fulfilled, so that the questionnaires can be distributed to all respondents. The criteria used in the pretest validity test are Kaiser-Meyer-Olkin (KMO), Barlett's Test of Sphericity, Anti-Images-Matrices (MSA), and Factor Loadings. Where the value of KMO should be $>0.5$, Barlett (sig) must be $<0.5$, MSA must be $\geq 0.5$, and factor loadings in the 
matrix component should be $\geq 0.6$ (Hair et al., 2010). Communalities and Total Variance Explained communalities should be $>0.5$ and the total variance explained should be $>60 \%$ (Malhotra, 2010). Result shows all items meet the validity criteria. The Cronbach's alpha results in the reliability test of pretest data also qualify, which is $>0.6$.

\section{RESULT AND DISCUSSION}

\section{Validity and Reliability}

Measurement of hypothesis 1 was perform using SEM method in accordance with Habibi et al. (2014) research. The proposed hypothesis is customer relationship with (a) product, (b) brand, (c) company, (d) other-customers in online brand community, positively affect brand trust.

From Table 1 it can be seen that all standardized loading factor or SLF of existing indicators is valid because the existing SLF has a value of $\geq$ 0.50 , except on the CC5 indicator which has a Loading Factor of $0.49(\leq 0.50)$. So in the next stage the CC5 indicator is removed from the measurement process. In terms of reliability measurement, all variables can meet reliability requirements, which according to Hair et al. (2006), reliability test requirements are CR $(\geq$ $0.7)$ and VE $(\geq 0.5)$.

\section{Hypotheses 1}

To test hypothesis 1 , structural equation modeling using LISREL 8.7 was used. the proposed model refers to Fig 1. ie the four customer-centric relationships (customer-product, customer-brand, customer-company, customer-other custmers) directly affect brand trust. Fit indices obtained in this measurement generally indicate good test criteria, ie $\chi 2171.00$ (p.00), RMSEA $=0.05$, GFI = $0.92, \mathrm{CFI}=0.99$

Table 1. Items Loading

\begin{tabular}{|c|c|c|c|c|c|c|}
\hline Construct & Items & Loading Factor & T Value & SLF & CR & VE \\
\hline \multirow[t]{3}{*}{ Customer-Product } & CP1 & 0.8 & 13.92 & 0.8 & 0.92 & 0.79 \\
\hline & $\mathrm{CP} 2$ & 0.85 & 15.13 & 0.85 & & \\
\hline & $\mathrm{CP} 3$ & 0.82 & 14.32 & 0.82 & & \\
\hline \multirow[t]{4}{*}{ Customer-Brand } & CB1 & 0.60 & 9.49 & 0.6 & 0.89 & 0.67 \\
\hline & CB2 & 0.78 & 13.67 & 0.79 & & \\
\hline & CB3 & 0.76 & 12.97 & 0.76 & & \\
\hline & CB4 & 0.79 & 13.80 & 0.79 & & \\
\hline \multirow[t]{4}{*}{ Customer-Company } & CC1 & 0.81 & 13.48 & 0.81 & 0.86 & 0.62 \\
\hline & $\mathrm{CC} 2$ & 0.56 & 8.28 & 0.56 & & \\
\hline & $\mathrm{CC} 3$ & 0.75 & 12.16 & 0.76 & & \\
\hline & $\mathrm{CC} 4$ & 0.68 & 10.70 & 0.68 & & \\
\hline \multirow[t]{3}{*}{ Customer-Other Customer } & Coc1 & 0.87 & 15.61 & 0.87 & 0.93 & 0.82 \\
\hline & $\mathrm{COC} 2$ & 0.86 & 15.41 & 0.86 & & \\
\hline & COC3 & 0.82 & 14.43 & 0.82 & & \\
\hline \multirow[t]{3}{*}{ Brand Trust } & BT1 & 0.88 & 15.47 & 0.88 & 0.92 & 0.80 \\
\hline & ВТ2 & 0.8 & 15.47 & 0.8 & & \\
\hline & Bt3 & 0.82 & 16.24 & 0.82 & & \\
\hline
\end{tabular}

Source: Prastowo (2019)

Table 2. Structural Relationship

\begin{tabular}{clcc}
\hline H1 & Relationship & T Value & Coefficient \\
\hline 1a & Customer-Product $\rightarrow$ Brand Trust & 0,61 & 0,11 \\
1b & Customer-Brand $\rightarrow$ Brand Trust & $\mathbf{3 , 7 8}$ & $\mathbf{0 , 9 4}$ \\
1c & Customer-Company $\rightarrow$ Brand Trust & $-1,87$ & $-0,17$ \\
1d & Customer-Other Customer $\rightarrow$ Brand Trust & 1,16 & 0,10 \\
\hline
\end{tabular}

Source: Prastowo (2019) 
In Table 2 it can be seen that only one variable has a significant and positive effect on brand trust, that is customer-brand relationship. Which is shown by the $t$-value that exceeds 1.96 . So it can be concluded on hypothesis 1 , only hypothesis $1 \mathrm{~b}$ is accepted. In this study the criteria used in testing hypothesis 1 is by comparing the result of $t$-value with the $t$-value table of the normal distribution table. The positive $t$-value of the normal distribution at $\alpha 5 \%$ is 1.96 , whereas for the negative-t table is -1.96 .

\section{Hypotheses 2}

Measurement of hypothesis 2 is done by using ANOVA method. The proposed hypothesis is Customer relationship with (a) product, (b) brand, (c) company, (d) other- customers in online brand community, stronger on high engagement customers, compared with low engagement customers. Thus to test hypothesis 2 will be measured as follows: the sample from community engagement will be divided into two groups based on the median that has been obtained, then will be seen the difference from both groups by using ANOVA method.

The median of the community engagement variable is 4.5. By using frequency distribution method number of samples of each level of engagement obtained, for instance high engagement level of 111 samples, and low level engagement as much as 109 sample. The mean score for high engagement is 5.11, while at low engagement is 3.63 .

Table 3. ANOVA Result

\begin{tabular}{lccc}
\hline Customer-centric & $\begin{array}{l}\text { Low } \\
\text { Engagement } \\
\text { Mean }\end{array}$ & $\begin{array}{l}\text { High } \\
\text { Engagement } \\
\text { Mean }\end{array}$ & $\begin{array}{l}\text { Sig. } \\
\mathbf{( p < 0 . 0 5}\end{array}$ \\
\hline Customer-Product & 4.09 & 5.25 & 0.000 \\
$\begin{array}{l}\text { Customer-Brand } \\
\text { Customer-Company }\end{array}$ & 4.06 & 5.05 & 0.000 \\
$\begin{array}{l}\text { Customer-Other } \\
\text { Customers }\end{array}$ & 3.75 & 4.21 & 0.000 \\
\hline
\end{tabular}

Source: Prastowo (2019)

Table 3 shows that there is a difference between the low engagement consumer group and the high engagement on all the variables in the online brand community (customer-product, customer-brand, customer-company, customer-other customers).

\section{Hypotesis 3 Moderating Effect of Community Engagement}

In this sub-section there will be 3 hypothesis to be tested, namely brand community engagement moderate the influence of four elements of online brand community (customer relationship with (a) product, (b) brand, (c) company, (d) othercustomers) to brand trust. Hypothesis 3 is tested by using SEM multisample method, this is in accordance with previous research (Habibie et al., 2014; Algesheimer et al., 2005). After obtaining samples for high engagement and low engagement, the baseline model is formed. The data processing obtained one basic model and four estimation multisample model. To analyze the result of the difference in this measurement, we calculate the difference from the value of chi - square $\left(\chi^{2}\right)$ by $\Delta \chi^{2}$ with $\mathrm{df}$ equal to $\Delta \mathrm{df}$, then the $\mathrm{p}$ value will be obtained. If the value of $p \leq 0.05$ then the difference of parameters analyzed between the groups is significant, whereas $p>0,05$ shows the difference of the parameters analyzed between the groups is not significant (Wijanto, 2015).

Table 4. The results of Multisample SEM Test Moderation Community Engagement

\begin{tabular}{|c|c|c|c|c|c|}
\hline Hypotheses & & Coef & $\chi^{2}$ & df & Prob \\
\hline Baseline Model & & & 183.51 & 109 & \\
\hline Customer- & $\mathrm{HE}$ & 0.56 & & & 0 \\
\hline Product $\rightarrow$ & LE & 0.18 & 187.29 & 110 & 0 \\
\hline Brand Trust & & & 3.78 & 1 & 0.051 \\
\hline Customer- & $\mathrm{HE}$ & 0.96 & & & 0 \\
\hline Brand $\rightarrow$ & $\mathrm{LE}$ & 0.85 & 188.7 & 110 & 0 \\
\hline Brand Trust & & & 5.19 & 1 & 0.022 \\
\hline Customer- & $\mathrm{HE}$ & -0.46 & & & 0 \\
\hline Company $\rightarrow$ & $\mathrm{LE}$ & 0.18 & 186.28 & 110 & 0 \\
\hline Brand Trust & & & 2.77 & 1 & 0.096 \\
\hline Customer- & $\mathrm{HE}$ & -0.07 & & 109 & 0 \\
\hline Other & LE & 0.18 & 185.33 & 110 & 0 \\
\hline Customers $\rightarrow$ & & & 1.82 & 1 & 0.177 \\
\hline Brand Trust & & & & & \\
\hline
\end{tabular}

Legend: HE = High Engagement, LE = Low Engagement Source: Prastowo (2019) 
From table 4 it can be seen that $\mathrm{P}$ value on customer-brand relationship to brand trust with moderating variable community engagement is $0,02(<0,05)$, coefficient on high engagement equal to 1,75 and on low engagement equal to 0,96 . Based on this we can see the difference, customer-brand relationships in high engagement customers have a stronger influence on brand trust compared with low-engagement customers. The results only support hypothesis $3 \mathrm{~b}$ whereas, this will be discussed further in the discussion section.

\section{Hypotesis 4 Moderating Effect of Brand Community Types}

Hypothesis 4 proposed in this study is that there are differences between consumer-initiated and company-initiated community types on the influence of customer-centric (customer relationships with (a) product, (b) brand, (c) company, (d) other- customers) to brand trust. Hypothesis 4 is tested using multisample SEM method. This testing process is similar to the process of testing hypothesis 3 , the difference is on samples classification into groups of moderating variables of brand community types, ie consumerinitiated and company-initiated types. Based on existing data, customer or community members of consumer-initiated numbered 117 respondents, while company-initiated type amounted to 103.

Table 5. The results of Multisample SEM Test Moderation Brand Community Types

\begin{tabular}{|c|c|c|c|c|c|}
\hline Hypotheses & & Coef & $\chi^{2}$ & df & Prob \\
\hline Baseline Model & & & 165.17 & 109 & \\
\hline Customer- & ConIn & -0.51 & & & 0 \\
\hline Product $\rightarrow$ & ComIn & 0.17 & 175.9 & 110 & 0 \\
\hline Brand Trust & & & 10.73 & 1 & 0.000 \\
\hline Customer- & ConIn & 1.54 & & & 0 \\
\hline Brand $\rightarrow$ & ComIn & 0.37 & 190.21 & 110 & 0 \\
\hline Brand Trust & & & 25.04 & 1 & 0.000 \\
\hline Customer- & ConIn & -0.25 & & & 0 \\
\hline Company $\rightarrow$ & ComIn & 0.17 & 172.91 & 110 & 0 \\
\hline Brand Trust & & & 7.74 & 1 & 0.003 \\
\hline Customer- & ConIn & 0.07 & & & 0 \\
\hline
\end{tabular}

\begin{tabular}{|c|c|c|c|c|c|}
\hline Other & ComIn & 0.17 & 165.62 & 110 & 0 \\
\hline Customers $\rightarrow$ & & & 0.45 & 1 & 0.502 \\
\hline Brand Trust & & & & & \\
\hline
\end{tabular}

Legend: ConIn = Consumer-Initiated Type, ComIn = Company-Initiated Type

Source: Prastowo (2019)

From Table 4 it can be seen that the results support H4a, H4b, and H4c. While H4d not show a significant difference. However, the influence of customer-product on brand trust (H4a) in the consumer-initiated community has resulted in opposite direction or negative, as well as the influence of customer-company on brand trust (H4d). this will be explained further in the discussion section.

\section{CONCLUSION}

\section{Discussion and Theoritical Implication}

Based on the results of this study can be seen that social media based brand community is different from the brand community in general. Social media facilitate members of brand community to interact each other and build customer-centric relationship in it. Results of this study differ from previous studies. Only customer-brand relationships that positively affect brand trust, the role of engagement also only moderate the influence of customer-brand relationships on brand trust. This study shows that there is a difference of influence on customer relationship with product, brand, and company to brand trust in consumer-initiated and company-initiated community types. However, the results are beyond our predictions, where the effect of customer relationships with products and companies on brand trust has a negative value on the type of consumer-initiated community, we present this discussion in the paragraph of hypothesis 4 results.

Customer-brand relationships or hypothesis 1 get results as per predictions, where customer-brand relationships within online brand community affect brand trust positively. The results also correspond to previous studies (Laroche et al., 2013; Habibi et al., 2014). In brand community, customers or community members play the role of an agent of the community brand (Muniz and 
O'Guinn, 2001). In addition, Muniz and O'Guinn (2001) stated that customer-brand relationships are the basic fundamentnal to a brand community. Therefore, the results of this study reinforce the statement and show that in the context of SMBBC customer-brand relationships are still vital to abrand community.

Based on observations that we have done, several aspects that differentiate SMBBC from conventional brand communities are: in SMBBC not all members are users of the product, there are members who are potential users or just want to follow the development of the brand, this is in accordance with unique aspect of SMBBC-based social media specified in the research of Habibi et al. (2014). Given some members who do not own the product of the brand, made it is possible to avoid any sense of pride in the product within the SMBBC. Jang (2008) revealed that companies can control content that could harm them, such as reviews or negative comments from customers. At SMBBC eWOM is very easy to occur, eWOM is a positive or negative expression created by potential customers, actual consumers, or former consumers about a product or company through the internet media (Hennig-Thurau Gwinner, Walsh, \& Gremler 2004). With the existence of a negative eWOM within an SMBBC enables the influence of customer-company and customer-other customer relationships on the brand trust insignificant.

The results of hypothesis 2 test are align with previous research conducted by Habibi et al. (2014). Customer relationship with product, brand, company, and other customers in online brand community is higher for customers in the high engagement category when compared to customers with low engagement category. A person with a high degree of engagement may considered as member that actively interacting in SMBBC. Interactions in social media-based SMBBC include: providing comments, likes, sharing information or experiences, sharing photos and videos related to the product or brand of the community. With so many interactions done within the community, a member will be attached to the four elements in the online brand community (product, brand, company and other customers) consciously or unconsciously. The level of interaction and participation of members within the community becomes one of the fundamental aspect in the online brand community (Brogi, 2014).

Testing of hypothesis 3 shows that the influence of customer-brand relationship to brand is stronger on high engagement customers compared with low engagement customers, while the other three relations have insignificant influence. Although brands often represent companies, but customer-brand and customer-company relationships are different. This can be seen from the indicators that construct these variables. Customer-brand relationship is more to customer's perception and their behavior towards the brand, for example: appreciate the historical value of the brand, assume the brand has a high quality, and recommendation. While the customer-company relationship is a customer perception of the interaction or behavior of companies or marketers in the online brand community. Therefore, different results between customer-brand relationship variables and customer-company can be considered as normal.

Based on the observations on SMBBC in this study, there are several possibilities that cause no significant differences in the influence of customer-product, customer-company, and customer-other customers relationships on brand trusts in high engagement and low engagement customers: SMBBC generally allows everyone to be a member without obligation to own or use the product of the brand, thus allowing the number of online members of the brand community to even reach millions. This leads to high levels of heterogeneity in the SMBBC, as well as the absence of brand community characteristics inherent within the community. Additionally, some online brand communities generally do not have a membership hierarchy (Habibi et al., 2014), so other members do not know the credibility of the shared information. 
Results of hypothesis 4 show that there is a difference on the influence of customer-product, customer-brand, and customer-company relationships on brand trust between consumerinitiated and corporate-initiated online brand community. Only one variable has insignificant value, that is customer-other customer relationship variable. The results obtained also align with Jang et al. (2008) research, where community types also moderate the influence of existing characteristics on the online brand community towards commitment and brand loyalty. In consumer-initiated community types, the influence of customer-brand relationships on brand trust is higher when compared to companyinitiated community types. Based on observations on several existing SMBBCs, most members of the consumer-initiated community type showcasing characteristics of the brand community as mentioned by Muniz and O'Guinn (2001), they are shared consciousness, rituals and traditions, and moral responsibility. In addition, the consumerinitiated community is self-managed by its members, so in general they have a strong characteristic to maintain the existence of their brand community. Given the members of the community are quite frequent being exposed to various things about the brand, and also have stronger brand community characteristics then resulted on the higher brand trust.

Amongst customers in consumer-initiated community type, relationship between the customer-product and brand trust is significant but show negative relationship. Some factors that may potentially caused this is the lack of pride in products owned by members of the community, but only proud of the brand that shelter it. Another possibility is that members do not have the product of the brand but have already become a member of the online brand community, this is very likely to occur in the context of online brand community in social media. Everyone easily join or leave the community, so it is not uncommon online brand community used as a place to search for reviews and recommendation of products to be purchased. In the consumer-initiated community type majority of the contents shared come from customers or members of the community, marketers or companies almost never directly interact in it, so the lack of interaction between customers and companies within a community can cause a negative impact on brand trust. Moreover, the notion that marketers are not open in providing information about the weaknesses of its products, so that community members put more confident in the information provided by fellow members of the community. Another result found in hypothesis 4 is that there is no significant difference in the influence of customer-other customers' relationships on brand trust in the consumer-initiated and company-initiated community types. Customer-other customer relationships are a matter of social media that companies or brands can not manage (Fournier and Avery, 2011). This shows that in social media customer relationships with other customers are very difficult to predict, sometimes it can provide benefits for companies with eWOM positive, or can turn to destroy the company with negative eWOM. Habibi et al. (2014) revealed that when there is e-WOM within customer-other customer relationships may leads to negative effect on brand trusts, even if those customers have high levels of interaction within the online brand community.

\section{Managerial Implication}

Results of this study indicate a difference between consumer-initiated and company-initiated. The negative influence of customer-product and customer-company relationships on brand trust in the consumer-initiated community is also a points to be considered by marketers. A strategy should be developed to improve customers' pride toward the products of the brand. Marketers should not only focus on building and managing their SMBBC, but also begin to establish relationships with consumer-initiated communities. This can be done by organizing brandfest events by engaging consumer-initiated community. Generally there is no cost to create a community in social media, making it possible to create subgroups related to a brand community, which will impact on multiple membership (Habibi et al., 2014; McAlexander, et al., 2002) . 
Marketers should look at these opportunities, in reality this can be done by creating chapters (eg chapter based on city or province). This will allow marketers to get closer to their customers from various chapters so they can retrieve information for future brand development.

In managing SMBBC most of the time marketers only measure the number of 'like', active members and visitors of the community page or site to measure the success of their community, marketers should explore further how to build loyalty, trust, idea generation, and used for market insight (Moran \& Gossieaux, 2001). In some studies engagement has proven its role in shaping commitment and brand trust. Higher engagement means higher co-operation and interaction, which through interaction will leads to a higher positive effect (Habibi et al., 2014). Based on this marketers must develop a strong stimulus that creates engagemen $t$ or high interaction in an online brand community, for example by considering hedonic benefits. Hedonic benefits are closely related to a comfortable, enjoyable, happy, pleasure and full of anthusiasm consumption experience (Kang, Tang, \& Fiore, 2014). Therefore, if community members feel happy, enjoy and entertained in the online brand community, then it can increase their engagement to the community.

\section{Limitation}

Social media is an area that is very difficult to control, the use of online questionnaires in this study causes the difficulty to understand whether the questionnaire is spread to the expected respondents. Thus, the results of this study can not be generalized to all social media based brand community in Indonesia. There is need for a research with larger research subject scales and deeper exploration of the types of brand communities. $90 \%$ of respondents in this study were male, so to avoid bias the next research can use gender as a moderation variable. Sample in this research consists of various products with different categories, thus create need for more specific research on product categories.

\section{REFERENCES}

Adjei, M., Noble, S., \& Noble, C. (2010). The influence of C2C communications in online brand communities on customer purchase behavior. Journal of the Academy of Marketing Science, 38 (5), 634-653.

Algesheimer, R., Dholakia, U. M., \& Herrmann, A. (2005). The social influence of brand community: Evidence from European car clubs. Journal of Marketing, 69(3), 19-34

Bagozzi, R. P., \& Dholakia, U. M. (2006). Antecedents and purchase consequences of customer participation in small group brand communities. International Journal of Research in Marketing, 23(1), 45-61

Brogi, 5. (2014). Online brand communities: a literature reviews. $2^{\text {nd }}$ World Conference On Business, Economics And Management.

Brodie, R. J., Hollebeek, L. D., Juric, B., \& Ilic, A. (2011). Customer Engagement. Journal of Service Research, 14(3), 252-271.

Casale, L. V., Flavian, C., \& Guinaliu, M. (2008). Promoting customer's participation in virtual brand communities: A new paradigm in branding strategy. Journal of Marketing Communications, 14(1), 19-36.

Chaudhuri, A., dan Holbrook, M, B. (2001). The chain of effect from brand trust and brand affect to brand performance: the role of brand loyalty. Journal of marketing, 65(2), 81-93.

Chen, H., Papazafeiropoulou, A., Chen, T.-K., Duan, Y., \& Liu, H.-W. (2014). Exploring the commercial value of social networks: Enhancing customers' brand experience through Facebook pages. Journal of Enterprise Information Management, 27(5),576-598. 
Chiu, C. M., Huang, H. Y., \& Yen, C. H. (2010). Antecedents of online trust in online auctions. Electronic Commerce Research and Application, 9,148-159.

D'Silva, Reynold. (2016, April 15). Almost All Internet Users in Indonesia Using Facebook. Retrieved from http://tekno.kompas.com/read/2016/04/15/10210007/

Etzioni, A., and Etzioni, O. (1999). Face-to-face and computer-mediated com munities: A comparative analysis. Information Society, 15,4,241-248.

Fournier, S., \& Avery, J. (2011). The Uninvited Brand. Business Horizons, 54(3), 193-207.

Gvili, Y., \& Levy, S. (2016). Antecedents of attitudes toward eWOM communication: differences across channels. Internet Research, 26(5), 1030-1051.

Habibi, M. R.., Laroche, M., Richard, M. O. (2014). The roles of brand community engagement in building brand trust on social media. Computer in Human Behavior, 37.

Hair, J. F., et al. (2006). Multivariate Data Analysis 6th Edition. New Jersey: Pearson Prentice Hall.

Hennig-Thurau, T., Gwinner, K. P., Walsh, G., \& Gremler, D. D. (2004). Electronic word-of- mouth via customeropinion platforms: What motivates customers to articulate themselves on the Internet? Journal of Interactive Marketing, 18(1), 38-52

Hur, W., Ahn, K., \& Kim, M. (2011). Building brand loyalty through managing brand community commitment. Management Decision, 49(7), 1194-1213.

Holmes, J. G. (1991). Trust and the appraisal process in close relationships. In W. H. Jones, D. Perlman, J. Kingsley, (Eds.), Advances in Personal Relationships 2 (pp. 57-104). London

Jang, H., Olfman, L., Ko, I., Koh, J., \& Kim, K. (2008). The influence of on-line brand community characteristics on community commitment and brand loyalty. International Journal of Electronic Commerce, 12 (3), 57-80.

Jing, Z., Sotheara, H., \& Virak, M. (2016). Virtual Community Engagement on Facebook Brand Page, 2(1), 7-13. https://doi.org/10.18775/jibrm.1849-8558.2015.17.3001

Jung, N. Y., Kim, S., \& Kim, S. (2014). Influence of consumer attitude toward online brand community on revisit intention and brand trust. Journal of Retailing and Consumer Services, 21(4), 581-589.

Moran, E., \& Gossieaux, F. (2001). Marketing in a hyper-social world: The tribalization of business study and characteristics of successful online communities. Journal of Advertising Research, 50(3), 232-239.

Kabadayi, S., \& Price, K. (2014). Customer - brand engagement on Facebook: liking and commenting behaviors. Journal of Research in Interactive Marketing, 8(3),203-223

Kang J., Tang, L., \& Fiore, A. M. (2014).Enhancing customer-brand relationships on restaurant Facebook fan pages : maximizing customer benefits and increasing active participation. International Journal of Hospitality Management, 36,145-155.

Kaplan, A. M., \& Haenlein, M. (2010). Users of the world, unite! The challenges and opportunities of social media. Business horizons, 53(1), 59-68.

Laroche, M., Habibi, M. R., Richard, M. O. (2013). To be or not to be in social media: how brand loyalty is affected by social media? International Journal of Information Management, 33.

Lee, D., Kim, H.S., Kim, J.K. (2011). The impact of online brand community type on customer's community engagement behaviors: customer-created vs. marketer-created online brand community in online social-networking websites. Cyberpsychol. Behav. Soc. Networking 14(1/2), 59-63.

Malhotra, Naresh K. (2010). Marketing Research ( $6^{\text {th }}$ Ed.). United State of America: Prentice Hall Inc.

McAlexander, James H., Schouten, John W., dan Koenig, Harold F. (2002). Building Brand Community. Journal of Marketing, Vol.66.

McWilliam, G. (2000). Building stronger brands through online communities. Sloan Manage. Rev. 41 (3), 43 54.

Muniz, M. A., \& O'Guinn, C. T. (2001). Brand community. Journal of Consumer Research, 27(4), 412-432. 
Powers, T., Advincula, D., Austin, M. S., Graiko, S., \& Snyder, J. (2012). Digital and social media in the purchase decision process: A special report from the Advertising Research Foundation. Journal of Advertising Research, 52(4), 479-489.

Rheingold, H. (2000) The Virtual Community: Homesteading on the Electronic Frontier. Cambridge, MA: MIT Press.

Schau, H. J., Muniz, A. M., \& Arnould, E. J. (2009). How brand community practices create value. Journal of Marketing, 73(5), 30-51.

Sung, Y., Kim, Y., Kwon, O., Moon, J. (2010). An explorative study of Korean customer participation in virtual brand communities in social network sites. J. Global Marketing 23 (5), 430-445.

Thompson, S. A., \& Sinha, R. K. (2008). Brand communities and new product adoption: The influence and limits of oppositional loyalty. Journal of Marketing, 72(6), 65-80.

Van Doorn, J., Lemon, K.N., Mittal, V., Nass, S., Pick, D., Pirner, P. and Verhoef, P.C. (2010). Customer engagement behavior: theoretical foundations and research directions. Journal of Service Research, Vol. 13 No. 3, pp. 253-266.

Wenger, E.; McDermott, R.A.; and Snyder, W. (2002). Cultivating Communities of Practice: A Guide to Managing Knowledge. Boston: Harvard Business School Press.

Wijanto, Setyo H. (2015). Metode Penelitian Menggunakan Structural Equation Modeling dengan Lisrel 9. Jakarta: Lembaga Penerbit Fakultas Ekonomi Universitas Indonesia

Wirtz, J., Ambtman, A. d., Bloemer, J., Horvath, C., Ramaseshan, B., Klundert, J. V.d., Canli, Z. G., Kandampully J., (2013). Managing brands and customer engagement in online brand communities, Journal of Service Management, Vol.24

Zhang, Y. (2015). The Impact of Brand Image on Consumer Behavior: A Literature Review. Open Journal of Business and Management, 3(01), 58.

Zaglia, M. E. (2013). Brand Communities embedded in social networks. Journal of Business Research, 66/ 